\title{
Location Determinants of Portuguese FDI in Poland
}

\author{
Patrycja Aleksandruk \\ Faculty of Economics \\ University of Porto \\ Rua Dr. Roberto Frias, \\ Porto 4200-464, Portugal \\ E-mail: patrycja.aleksandruk@gmail.com \\ Rosa Forte \\ Faculty of Economics \\ University of Porto and CEF.UP \\ Rua Dr. Roberto Frias, \\ Porto 4200-464, Portugal \\ E-mail: rforte@fep.up.pt
}

Abstract: In recent years, Poland has become one of the most attractive locations for foreign investment and has strengthened its position in Central and Eastern Europe (CEE) and throughout Europe. The aim of this paper is to analyse what makes Poland an attractive market for foreign investors, to offer a better understanding of reasons why Poland is a more attractive location compared to its neighbours in the CEE. After surveying Portuguese investors in Poland, our results indicate that the most significant factor determining locating a business in Poland is its large domestic market. Poland's location is also appreciated by Portuguese investors while deciding on FDI. As indicated by Portuguese investors, the most important obstacles to investment in Poland are language barriers, cultural differences and bureaucracy. These results are relevant for companies who wish to invest in Poland and can also assist policymakers in designing policies to attract FDI.

Keywords: Foreign Direct Investment, Poland, Poland's attractiveness, Portuguese investors 


\section{Introduction}

One of the most important trends in today's economy is the internationalisation of businesses. This is one of the biggest challenges for enterprises of all sizes, but every year more and more companies go international for reasons such as increasing competition in their home country, technological advantages, tax benefits, saturation of the domestic market, or the possibility of extending product life cycles (Morschett et al., 2010).

Internationalisation can occur in different ways such as exports, licensing, franchising, and foreign direct investment (FDI) (Sharan, 2012). FDI involves the injection of foreign funds into a company operating in a different country than the origin of the investor. Broad definitions of FDI are provided by international institutions such as the Organisation for Economic Co-operation and Development (OECD) and the United Nations Conference on Trade and Development (UNCTAD). UNCTAD defines FDI as "an investment involving a long-term relationship and reflecting a lasting interest and control of a resident entity in one economy (foreign direct investor or parent enterprise) in an enterprise resident in an economy other than that of the foreign direct investor (FDI enterprise or affiliate enterprise or foreign affiliate)" (UNCTAD, 1999 , p. 465). Furthermore, according to the OECD recommendations, in order to qualify as FDI a foreign investor should own at least 10 per cent of ordinary shares or voting power (OECD, 2008, p. 23). Having chosen to enter the foreign market through FDI, the company has to decide on the level of control/ownership by choosing between a joint venture (JV) and a wholly owned subsidiary (WOS) (Anil et al., 2014). A JV is a shared equity relationship, in contrast to a whollyowned subsidiary, which represents full control over foreign business entities and 100 per cent of ownership. In addition to the level of control, the company has to decide on the mode of establishment: acquisition of a local company or building a new plant (greenfield project) (Anil et al., 2014).

There are numerous reasons why FDI has become a widely discussed topic. FDI creates long-lasting and stable links between economies; it is a crucial element in international economic integration; FDI encourages the transfer of technology between countries (Morschett et al., 2010). Foreign affiliates of multinational enterprises (MNEs) account for about one-third of the world exports (UNCTAD, 2002). Furthermore, foreign subsidiaries' sales in the host countries increased faster than total global exports (Cherunilam, 2008). Other relevant data: in 2006, 73 million people were employed by the foreign affiliates of MNEs, compared to 25 million in 1990 (Cherunilam, 2008). These are some of the reasons why FDI 
is such an important topic in the economic literature. There are many motives that encourage companies to produce abroad and engage in FDI, which are synthesised by Dunning and Lundan (2008): resource seeking, market seeking, efficiency seeking and strategic asset seeking.

Poland is one of the few countries in Europe which has done well during the recent crisis, although the Polish market economy is only about 25 years old. According to the World Bank Doing Business 2013 report, Poland was the top improver globally in 2012. It has won consistent attention as the fastest growing European Union member since 2008. What is more interesting, in 2012 Poland overtook Russia to become the leading destination for FDI projects in the CEE, according to Ernst \& Young's (2013) attractiveness survey. In the annual survey conducted by the United Nations Conference on Trade and Development (UNCTAD) where investors were questioned about the most attractive countries for investment in 2013-2015, Poland is ranked fourth in Europe and fourteenth in the world (UNCTAD, 2013).

The aim of this paper is to analyse what makes Poland such an attractive market for Portuguese investors, gaining a better understanding of the reasons why Poland is a preferred location compared to its neighbours in Central and Eastern Europe, and why each year more and more Portuguese investors choose Poland for investment. From this we defined the following research question: What are the most important location factors underlying Portuguese FDI in Poland?

The reason for focusing on Portuguese FDI in Poland is related to several factors. Firstly, according to Agência para o Investimento e Comércio Externo de Portugal (AICEP, 2013), in 2012 the Portuguese FDI in Poland amounted to 112 million euros, and while representing a significant decrease of 49.7 per cent compared to 2011, Poland is still among the biggest investment markets, ranked eighth (after the Netherlands, Spain, Brazil, Angola, Luxembourg, USA, and UK) and it is by far the most important market for Portuguese companies in the CEE. Moreover, the Polish-Portuguese Chamber of Commerce (PPCC) is the third largest Portuguese Chamber of Commerce in Europe and the fourth largest in the world, which shows that relations between both countries are becoming more and more important (PPCC, 2013). Additionally, despite the economic crisis which has beset Portugal, Portuguese companies are attracted to doing business with their Polish counterparts and in investing in Poland.

Although there are some studies regarding the determinants of FDI in Poland (e.g., Cieślik, 2013; Chidlow et al., 2009; Gorynia et al., 2007), to the best of our knowledge there is none that focuses on the case of Portuguese FDI in the 
country. Furthermore, most of the existing studies focus on the determinants from a macro perspective and not from a micro perspective. In this way, the present study adopts a micro perspective through a survey to Portuguese investors in Poland. Since only 20 responses to the questionnaire were obtained no generalisations can be made. Thus, this work should be seen as a preliminary study which could serve as a starting point for a larger-scale research.

The paper is organised as follows. Section 2 provides a characterisation of the Polish-Portuguese investment relations. The literature review is provided in Section 3, divided into two sections, including location determinants of FDI (3.1), and FDI in Poland (3.2). Section 4 presents the data collection and a brief characterisation of the sample. Section 5 reports the main results regarding the localisation factors (5.1) and obstacles (5.2). The final section includes the main conclusions, limitations and suggestions for future research.

\section{Portuguese-Polish investment relations}

Poland and Portugal have established and been strengthening cooperation in the field of investment for many years. As it was mentioned in the first section of this paper, according to AICEP, Poland has been recognised as attractive for the development of Portuguese companies and also as a country with a high business potential, among others such as Great Britain, France and Germany (AICEP, 2013). Figure 1 presents the total outflow in the net values of Portuguese FDI to Poland over the eleven years from 2003 to 2013.

Over this decade, Portuguese FDI outflow to Poland is characterised by instability and inconsistent trend. ${ }^{1}$ In 2003, Portuguese FDI in Poland had a negative value, that is, there was a net capital outflow from Poland. Thus, Poland was in $49^{\text {th }}$ position in the ranking of target markets for Portuguese investment abroad. From 2004 to 2006, the inflow of Portuguese FDI started to increase gradually. In 2006, Portuguese FDI in Poland was almost 7 per cent of the total value of Portuguese FDI. At that time Poland reached the third position among all the target markets for Portuguese FDI, its highest position over the 11 years shown, according to AICEP (2014). A decreasing trend in the inflow of Portuguese FDI to Poland was reported in the years 2007-2009. The year with

1 It can be noticed that since 2007 total Portuguese FDI outflows have been affected by the global financial and economic crisis. In 2010, total Portuguese FDI outflows were strongly affected by the crisis, with the lowest flows in the declining trend since 2005 (Simões \& Cartaxo, 2012). 
Figure 1. Total flow of Portuguese FDI to Poland in 2003-2013 (expressed in mln euros), net values

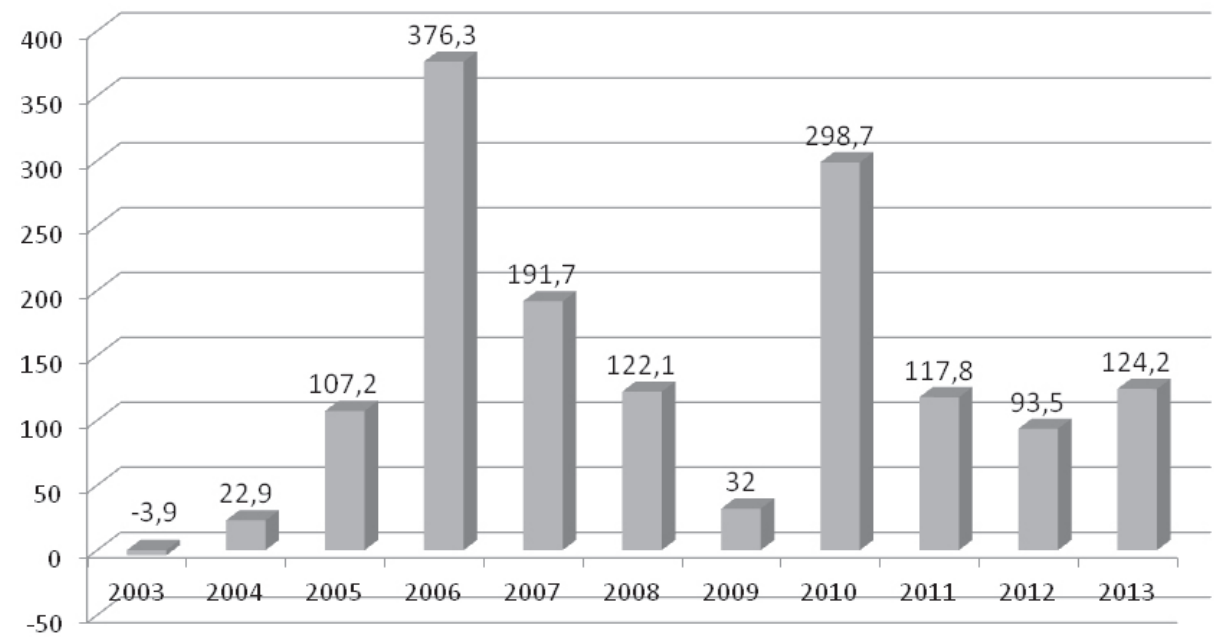

Source: Own elaboration based on data obtained from AICEP (2014)

the worst results was 2009, when the Portuguese FDI to Poland represented approximately 5 per cent of the total Portuguese FDI. The position of Poland in the ranking of target markets for Portuguese investors fell to the eleventh place. Mention should also be made of the significant rise in 2010. Portuguese FDI outflow to Poland amounted to 298.7 million euros, representing a whopping 266.7 million euros more than in the previous year, with Poland representing the second main destination for Portuguese investment. A decreasing trend was again seen in 2011-2012 when the value of Portuguese FDI in Poland dropped, with Poland falling to the eighth and fifth position among all target markets for Portuguese FDI. The year 2013 brought an increase and the value of Portuguese FDI in Poland rose by almost 31 million euros over 2012. Poland's position among Portuguese target markets to investment also increased and reached $3^{\text {rd }}$ place in the ranking. ${ }^{2}$

Regarding Poland's FDI inflows, Figure 2 presents the inflow of Portuguese FDI into Poland over the same eleven years. ${ }^{3}$

2 Poland's position was calculated based on data obtained from the Agência para o Investimento e Comércio Externo de Portugal (AICEP).

3 It should be noted that Figure 1 and Figure 2 present similar data, but there are some differences between them. The reason is that the data was obtained from two different organisations from different countries. Because of this, statistics usually differ between the investing economy and the host economy. 
Figure 2. FDI inflows to Poland from Portugal in the years 2003-2013 (expressed in m/n euros), net values

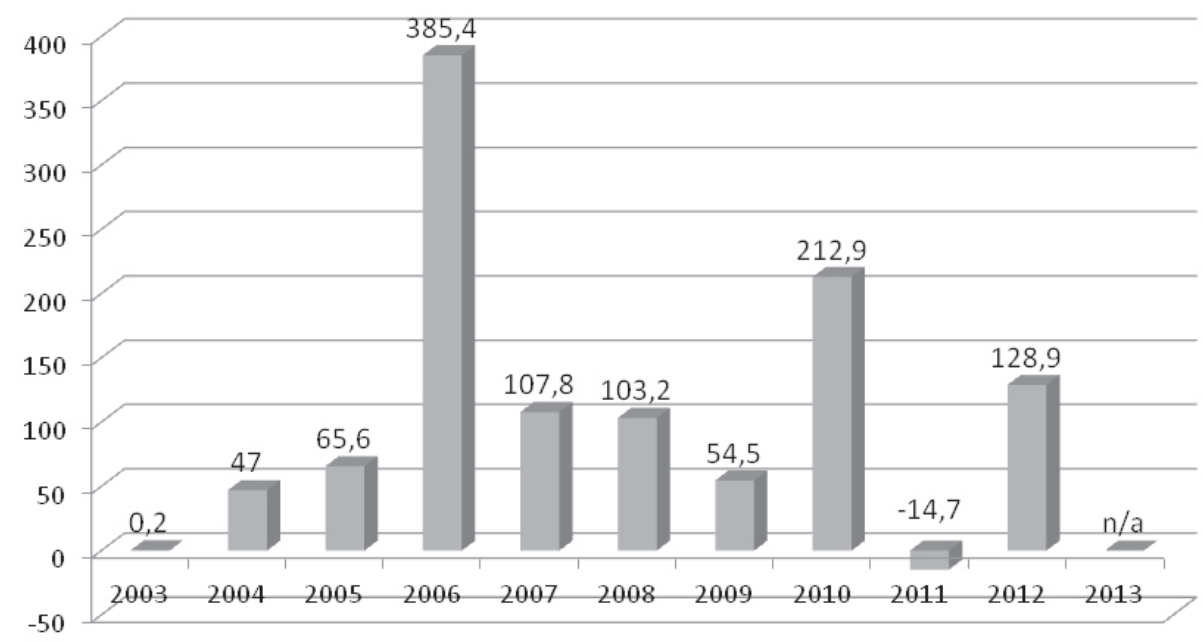

Source: Own elaboration based on data obtained from the National Bank of Poland (NBP), accessed at http://www.nbp.pl

When analysing the inflow of Portuguese FDI to Poland in 2003-2013, it can be noted that the trend was also unstable. ${ }^{4}$ The value of Portuguese FDI rose gradually until 2005, and then shot up in 2006. In 2006, Portugal reached the eleventh position among all foreign investors in Poland and the value of Portuguese investment was almost 3 per cent of total FDI in Poland. ${ }^{5}$ The years 2007-2012 saw fluctuations on the importance of Portugal as a foreign investor for Poland. The worst result was recorded in 2011 when Portugal reached the $189^{\text {th }}$ position among all foreign investors in Poland. In 2012, the value of Portuguese FDI in Poland rose again to almost 130 million euros, and Portugal reached the $14^{\text {th }}$ position.

After analysing the position of Poland among all the target markets for Portuguese FDI and the position of Portugal among all foreign investors in Poland, it can be noticed that Poland is a more important target market for Portugal than Portugal is for Poland as a foreign investment location.

The attractiveness of the Polish market as a destination for Portuguese FDI is

$4 \quad$ It should be highlighted that the inflow of FDI to Poland in the years 2008-2010 was also affected by the global crisis. The FDI inflow to Poland dropped significantly during those years.

5 Portugal's position was calculated based on data obtained from the National Bank of Poland (NBP). 
confirmed by the steady growth of the number of subsidiaries of Portuguese companies in Poland. According to the AICEP, at the end of 2011, there were 110 companies with Portuguese capital operating in Poland and in 2012 this number increased to 125 . These companies operate in the retail and service industry (import and distribution of agricultural and food products, pharmaceuticals, interior decoration products, textiles, etc.), services, real estate and property development industry, the energy sector (mainly renewable energy), the building industry, advisory and legal services, the industrial sector, finance and banking, the food industry, IT, hotels, textile and clothing industry, environmental protection and the medical industry (Embaixada da República da Polónia em Lisboa, 2014).

\section{Literature review}

\subsection{Location determinants of FDI}

The economic literature on this topic pays special attention to the determinants of the FDI location by multinational companies. According to Dunning's (1980) eclectic paradigm or OLI paradigm, a country attracts FDI based on locationspecific advantages it offers. Dunning identified three conditions that determine undertaking FDI: ownership advantages - $\mathrm{O}$ (such as a competitive advantage that can include access to natural resources, to highly trained and skilled personnel or to new technology); location advantages - $\mathrm{L}$ (where the company derives greater benefits than in the home country); and specific advantages of internalisation - I (it is better for the companies to exploit a foreign opportunity themselves rather than through agreements with foreign firms (Morschett et al., 2010). Ownership advantages are necessary so that a foreign company has specific advantages over local companies in the host countries. If this condition is met, a company can realise advantages by internalising transactions. If the first two conditions are met, a company will invest overseas if location advantages exist (Klug \& Pietrzak, 2006). The key assertion is the fact that all three factors are essential when determining the extent and pattern of FDI. The eclectic paradigm provides a broader outlook to explaining FDI. (Shenkar \& Luo, 2007) As this study aims at investigating FDI location determinants in Poland, the main perspective is evidently on the L parameter of Dunning's eclectic paradigm.

The location advantage refers to the advantage of locating an investment in a specific location because of its unique characteristics (Dunning \& Lundan, 2008), making a specific foreign country a more attractive location than others. For example, transport costs may be too high to serve these markets through 
exports. Location advantages also involve economic, institutional and political characteristics, such as large domestic markets, access to natural resources, a highly educated labour force with low labour costs, and political stability, among others. It should be noted that terms such as 'determinants' and 'motivations' regarding foreign direct investment are interrelated. Determinants represent the country perspective and motivations are considered from the perspective of the company (UNCTAD, 2003). In 1988, British economist John Dunning identified four main groups of motives for companies to produce abroad (engaging in FDI) which are synthesised in Dunning and Lundan (2008): resource seeking, market seeking, efficiency seeking, and strategic asset seeking.

The main goal of resource-seeking FDI is to secure access to specific minerals, raw materials or a pool of "unskilled" or "semi-skilled" labour and infrastructure which is required for production and is too expensive or not available in the company's home country (Dunning \& Lundan, 2008). Market-seeking FDI is mainly focused on gaining access to new foreign markets or expanding and developing already existing markets. (Dunning \& Lundan, 2008). Efficiencyseeking FDI occurs when a company transfers its production (totally or partially) to low labour cost locations in order to increase their cost efficiency and to improve the profitability of its overall operations (Dunning, 1998). Finally, strategic asset-seeking FDI aims at improving international competitiveness through access to foreign markets, organisational and marketing techniques and technologies. A company uses FDI to gain strategic assets that might be crucial to its long-term strategy but are unavailable in its home country. They are mainly undertaken through acquisitions and mergers (Dunning, 1998). This classification of FDI motives is very popular in economic literature and it is also used in the UNCTAD's World Investment Reports (UNCTAD, 1998). A scheme identifying the location determinants or the country selection criteria by type of investment is set out in Table 1.

Apart from economic determinants by type of investment, Dunning and Lundan (2008) also set out the factors related to the general policy framework as well as specific policies for FDI. With respect to the general policy framework the authors mention stability of the business environment (economic, political and social); government effectiveness; and policies related to international trade, competition, among others. Concerning the specific policies for FDI, Dunning and Lundan (2008) report "investment incentives, bilateral international investment agreements," investment support services, and social facilities. 
Table 1. Location determinants of FDI by type

\begin{tabular}{|c|c|c|c|}
\hline $\begin{array}{l}\text { Market-seeking } \\
\text { investment }\end{array}$ & $\begin{array}{l}\text { Resource-seeking } \\
\text { investment }\end{array}$ & $\begin{array}{l}\text { Efficiency- } \\
\text { seeking } \\
\text { investment }\end{array}$ & $\begin{array}{l}\text { Asset-seeking } \\
\text { investment }\end{array}$ \\
\hline $\begin{array}{l}\text { Size and growth of } \\
\text { local market; } \\
\text { Ability to access to } \\
\text { adjacent/regional } \\
\text { markets; } \\
\text { Consumer } \\
\text { preferences; } \\
\text { Market structure; } \\
\text { Psychic distance. }\end{array}$ & $\begin{array}{l}\text { Costs of land, } \\
\text { buildings, raw } \\
\text { materials, } \\
\text { components and } \\
\text { parts; } \\
\text { Reduced cost of } \\
\text { unskilled labour; } \\
\text { Availability of } \\
\text { skilled labour and } \\
\text { the respective cost. }\end{array}$ & $\begin{array}{l}\text { Costs of resources } \\
\text { (land, buildings, } \\
\text { raw materials, } \\
\text { labour, etc.) } \\
\text { coupled with labour } \\
\text { productivity } \\
\text { Transport and } \\
\text { communication } \\
\text { costs; } \\
\text { Member of a } \\
\text { regional integration } \\
\text { agreement; } \\
\text { "Quality of } \\
\text { market-facilitating } \\
\text { institutions" }\end{array}$ & $\begin{array}{l}\text { Competition policy, } \\
\text { particularly in terms } \\
\text { of mergers and } \\
\text { acquisitions } \\
\text { Various created } \\
\text { assets, such as } \\
\text { technological, } \\
\text { managerial, and } \\
\text { relational assets; } \\
\text { Quality of } \\
\text { infrastructures, } \\
\text { such as tele- } \\
\text { communications, } \\
\text { roads, among } \\
\text { others. }\end{array}$ \\
\hline
\end{tabular}

Source: Adapted from Dunning and Lundan, 2008, p. 325.

\subsection{FDI in Poland: motives and determinants}

FDI location determinants have been broadly discussed in the literature, but few empirical studies focus on the motives for foreign direct investment in CEE, mainly in Poland.

The market entry strategies of UK companies in Poland were analysed by Ali and Mirza (1996). According to their results, the most important motives for investing in Poland are the strategic location of Poland; obtaining higher profits; penetrating markets; being ahead of the competition; and establishing a local presence. These results seem to indicate that for UK companies starting activities in Poland, market-seeking factors are the most important.

Cieślik (2005a) focused in his research on the location determinants of foreign companies in Poland in the period of 1993-1998 at a regional level, that is, for 49 former voivodeships. ${ }^{6}$ The result of this study showed that the concentration

6 Voivodeships, or provinces, are units of local self-government of the third tier (Czerny, 2006). It refers to the area administered by a voivode in several countries of Central and Eastern Europe. It has been a high-level administrative subdivision of Poland since the $14^{\text {th }}$ century. In 1999, forty-nine former voivodeships were replaced by sixteen new ones. 
of foreign firms was positively related to the road network and service and industry agglomeration and negatively related to the unemployment rate. Cieślik's follow-up study (Cieślik, 2005b) focused on the role of the border effect in this country. He found that the regions of Poland that shared borders with Eastern non-EU countries were less attractive to foreign investors than regions that shared borders with EU member countries.

Cieślik and Ryan (2005) conducted their investigation on the location determinants of Japanese companies in Poland using a data set from 1991 to 2001. Special attention was put on the Special Economic Zones (SEZ) that were created in Poland during this period. Their findings showed that SEZs do not attract Japanese foreign direct investment. The authors explain that the reason for this situation might be the fact that taxes in general do not play a significant role in location decisions of Japanese investors. Thus, Polish tax incentives do not influence multinational corporations from Japan.

Polish economists Gorynia, Nowak and Wolniak (2007) focused on the motives and modes of foreign direct investment in Poland. They conducted a complex analysis of the survey results of seven subsidiaries of multinational corporations (MNC) that started business activity in Poland in the early nineties. The findings of this study indicate that the main motives for undertaking FDI were marketand efficiency-seeking factors (firms look for lower costs of production and transport, expansion and improvement of market position, low-cost highly qualified labour force, among others). No company indicated resource-seeking factors as fundamental for undertaking the investment.

In addition to FDI motives, Gorynia, Nowak and Wolniak (2007) also analysed the mode of establishment. According to their results, the main reason for choosing a greenfield mode is the ability to adjust the scale of operations and strategies to the market requirements, which is in line with Dunning's market-seeking motives. However, the acquisition mode is chosen because of the reduced time in moving into the new market. Furthermore, the study did not show any clear pattern in the relationship between the motives and modes of FDI.

Torrisi and others (2007) explored the determinants of FDI in Poland since economic transition to a full market economy began in late 1989. Their study emphasises the fact that Poland is the major recipient of FDI in the CEE region and has the largest dynamic emerging economy, which in less than twenty years has successfully transitioned to an almost fully liberalised market. The results of their empirical analysis confirm that exchange rates, corporate taxes and openness to trade and investment were significant determinants of FDI. The 
variable associated with wages was not significant. The significance of accession to the European Union was not validated as a determinant to FDI in Poland. Moreover, this study confirmed that for economies in transition, market size and rate of growth are critical factors in FDI attractiveness. One of the important findings in this study is the significance of corporate taxes in attracting FDI. The reduction of corporate tax rates is a strong incentive for foreign investors to locate in an economy in transition (Torrisi et al., 2007).

Chidlow and others (2009) examined the motives for the inflow of foreign capital into Poland at the regional level. In order to conduct the survey, a list of 1,243 MNEs was obtained, where 148 respondents were randomly selected for a pilot study (65\% of participants were of European origin and $35 \%$ nonEuropean). The final study was conducted with 91 respondents, which represents 15 per cent of initially contacted firms. The result showed that the Mazowieckie region is most often selected by those investors for whom agglomeration, knowledge and market factors are the main motives for investing in Poland. Furthermore, investors for whom low costs, availability of labour and resources and geographical factors are crucial motives for starting a business activity in Poland chose regions other than the Mazowieckie area. These results confirm that the various regions in Poland differ substantially in attracting FDI and that regional characteristics matter in the selection process.

In 2010, the TPA Horwath Polska consulting company, together with the Polish Portuguese Chamber of Commerce (PPCC), conducted a study among Portuguese investors in Poland (TPA Horwath, 2010). This research aimed at indicating the most popular locations of Portuguese FDI, their main features, identifying the obstacles faced by Portuguese investors in Poland and gaining a better understanding about the possibilities of benefiting from the support of Polish institutions. The survey was conducted from March to April 2010 with an interactive questionnaire sent to 80 companies with Portuguese capital located in Poland. Thirty per cent of the companies sent back properly completed questionnaires. The results showed that the majority of Portuguese companies are located in the Mazowieckie and Wielkopolskie regions. The Łódzkie, Śląskie and Zachodniopomorskie regions are clearly underestimated by investors from Portugal.

Portuguese companies located in the Mazowieckie Voivodeship operate mainly in the services sector (i.e. banking, consulting, insurance and tourism) and the energy sector. The study also showed that the majority of Portuguese investments in Poland are greenfield investments. Most of the companies are entirely dependent on Portuguese capital. Although 33 per cent of companies 
have less than 100 per cent of Portuguese capital, in most cases the capital in majority is Portuguese. Moreover, most of the companies operate only in the Polish market. Investors from Portugal consider the size and potential of the Polish market as favourable. In addition, for some of them, Poland offers the only possibility to export to eastern markets. They pointed out that they do not cooperate with local entrepreneurs when starting a business in Poland. Ninetytwo per cent of respondents maintain trade relations with other Polish companies with Portuguese equity. The survey results showed that Portuguese entrepreneurs do not benefit from any support from EU funds and do not cooperate with Polish entities during the investment process. The majority of Portuguese entrepreneurs valuate the PPCC performance as very good and helpful.

According to the investors from Portugal, the main obstacles of the Polish market are weak public administration and time-consuming bureaucratic procedures, language barriers, difficulties in hiring qualified workers, and the advantage that existing companies have.

Lastly, the most recent research of Cieślik (2013) also focused on the determinants of foreign companies' location in Poland, but this time special attention was put on the role of firm size. A test was run in order to measure the significance of particular location determinants related to regional characteristics, using as dependent variables the number of foreign companies included in each size category (micro, small, middle-size and large firms) in each region in a given year. The study provides an important list of determinants/motives of FDI in Poland such as factor costs, infrastructures, borders, R\&D expenditures, among others. Cieślik also confirmed the role of border effects reported in his previous study (2005b).

Table 2 summarises the studies described above to provide an overview of the papers.

Table 2. Literature review summary

\begin{tabular}{|l|l|l|l|l|}
\hline Authors & Aim of study & Method & $\begin{array}{l}\text { Level of } \\
\text { analysis }\end{array}$ & Results \\
\hline $\begin{array}{l}\text { Ali and } \\
\text { Mirza } \\
(1996)\end{array}$ & $\begin{array}{l}\text { Market entry } \\
\text { strategies of } \\
\text { UK companies } \\
\text { in Poland }\end{array}$ & Survey & Firms & $\begin{array}{l}\text { Most important motives: } \\
\text { strategic location of Poland, } \\
\text { obtaining higher profits, } \\
\text { penetrating markets; being } \\
\text { ahead of the competition } \\
\text { and establishing a local } \\
\text { image }\end{array}$ \\
\hline
\end{tabular}




\begin{tabular}{|c|c|c|c|c|}
\hline $\begin{array}{l}\text { Cieślik } \\
\text { (2005a) }\end{array}$ & $\begin{array}{l}\text { Location } \\
\text { determinants } \\
\text { of foreign } \\
\text { companies } \\
\text { in Poland in } \\
\text { the period of } \\
1993-1998 \text { at a } \\
\text { regional level }\end{array}$ & Regression & Firms & $\begin{array}{l}\text { Concentration of foreign } \\
\text { firms positively related to the } \\
\text { road network and service } \\
\text { and industry agglomeration, } \\
\text { and negatively related to the } \\
\text { unemployment rate }\end{array}$ \\
\hline $\begin{array}{l}\text { Cieślik } \\
\text { (2005b) }\end{array}$ & $\begin{array}{l}\text { The role of } \\
\text { border effect in } \\
\text { the country }\end{array}$ & $\begin{array}{l}\text { Negative } \\
\text { binomial } \\
\text { regression }\end{array}$ & Country & $\begin{array}{l}\text { Polish regions that share } \\
\text { borders with Eastern EU } \\
\text { non-accessing countries } \\
\text { were less attractive to } \\
\text { foreign investors than } \\
\text { regions which share borders } \\
\text { with EU member countries }\end{array}$ \\
\hline $\begin{array}{l}\text { Cieślik } \\
\text { and } \\
\text { Ryan } \\
(2005)\end{array}$ & $\begin{array}{l}\text { Location } \\
\text { determinants } \\
\text { of Japanese } \\
\text { MNEs in } \\
\text { Poland with a } \\
\text { focus on SEZ }\end{array}$ & $\begin{array}{l}\text { The Poisson } \\
\text { regression } \\
\text { model }\end{array}$ & Firms & $\begin{array}{l}\text { SEZs do not serve to attract } \\
\text { inward Japanese FDI }\end{array}$ \\
\hline $\begin{array}{l}\text { Gorynia } \\
\text { et al. } \\
(2007)\end{array}$ & $\begin{array}{l}\text { Motives and } \\
\text { modes of FDI in } \\
\text { Poland }\end{array}$ & $\begin{array}{l}\text { Case study; } \\
\text { Personal } \\
\text { interviews } \\
\text { with a } \\
\text { structured } \\
\text { question- } \\
\text { naire }\end{array}$ & Firms & $\begin{array}{l}\text { The formulation of crucial } \\
\text { hypotheses that serve as } \\
\text { possible guidelines for } \\
\text { undertaking future research }\end{array}$ \\
\hline $\begin{array}{l}\text { Torrisi } \\
\text { et al. } \\
(2007)\end{array}$ & $\begin{array}{l}\text { Determinants } \\
\text { of FDI in } \\
\text { Poland during } \\
\text { the period } \\
\text { of transition } \\
\text { 1989-2006 }\end{array}$ & $\begin{array}{l}\text { Dynamic } \\
\text { panel } \\
\text { regression; } \\
\text { the Wald } \\
\text { test; } \\
\text { the Arellano- } \\
\text { Bond } \\
\end{array}$ & Country & $\begin{array}{l}\text { Exchange rate, corporate } \\
\text { taxes and openness to } \\
\text { trade and investment } \\
\text { were significant; Variables } \\
\text { associated with wages and } \\
\text { accession to the EU were } \\
\text { not crucial determinants of } \\
\text { FDI }\end{array}$ \\
\hline $\begin{array}{l}\text { Chidlow } \\
\text { et al. } \\
\text { (2009) }\end{array}$ & $\begin{array}{l}\text { Motives of FDI } \\
\text { inflows into } \\
\text { Poland at the } \\
\text { regional level }\end{array}$ & $\begin{array}{l}\text { Survey; } \\
\text { Multinomial } \\
\text { logit model }\end{array}$ & Country & $\begin{array}{l}\text { The Mazowieckie region } \\
\text { is most often selected by } \\
\text { those investors for whom } \\
\text { agglomeration, knowledge } \\
\text { and market factors are the } \\
\text { main motives for investing in } \\
\text { Poland }\end{array}$ \\
\hline $\begin{array}{l}\text { TPA } \\
\text { Horwath } \\
(2010)\end{array}$ & $\begin{array}{l}\text { Portuguese } \\
\text { investment in } \\
\text { Poland }\end{array}$ & Survey & Firms & $\begin{array}{l}\text { For Portuguese investors } \\
\text { the main obstacles to the } \\
\text { Polish market are weak } \\
\text { public administration and } \\
\text { time-consuming procedures, } \\
\text { language barriers, difficulties } \\
\text { in hiring qualified workers } \\
\text { and the advantages that } \\
\text { existing companies have }\end{array}$ \\
\hline
\end{tabular}




\begin{tabular}{|l|l|l|l|l|}
\hline $\begin{array}{l}\text { Cieślik } \\
(2013)\end{array}$ & $\begin{array}{l}\text { Determinants } \\
\text { of foreign } \\
\text { companies' } \\
\text { location in } \\
\begin{array}{l}\text { Poland (special } \\
\text { focus on the } \\
\text { role of firm } \\
\text { size) }\end{array}\end{array}$ & $\begin{array}{l}\text { The Poisson } \\
\text { and negative } \\
\text { binomial } \\
\text { models. }\end{array}$ & Country & $\begin{array}{l}\text { Determinants/motives of } \\
\text { FDI in Poland: factor costs, } \\
\text { infrastructures, borders, }\end{array}$ \\
& & & $\begin{array}{l}\text { R\&D expenditures, etc.; } \\
\text { Confirmation of the role of } \\
\text { border effects reported in his } \\
\text { previous studies }\end{array}$ \\
\hline
\end{tabular}

Source: Own elaboration

The above papers present different levels of analysis and different methodologies of research. All of these studies play a significant role in gaining a better understanding about the determinants and motivations of investors undertaking FDI in Poland, provide necessary information and help in directing the present research on Portuguese FDI and Portuguese investors in Poland. However, half of these studies focus on a macroeconomic perspective, which does not allow understanding the company's view.

The research of TPA Horwath Polska and PPCC and the study conducted in the present paper share some similarities, but also have important differences. Both studies focus on Portuguese investors in Poland. The study presented in this subsection pays more attention to data regarding employment and management structure obstacles in the Polish market. The study conducted in this paper focuses mainly on the motives of Portuguese companies investing in Poland and the importance of location factors underlying Portuguese FDI in Poland.

\section{Data collection and a brief characterisation of the sample}

This paper aims to examine what makes Poland an attractive market for foreign investors to gain a better understanding of why Poland is such an interesting location nowadays, and why each year more and more Portuguese investors choose Poland for investment. Primary data was collected by conducting a questionnaire among Portuguese companies in Poland in order to provide a meaningful analysis. Secondary data information was also collected to support the research. In this study several databases were used: databases of UNCTAD, OECD, Polish Information and Foreign Investment Agency (PAIiIZ), the Portuguese Business Development Agency (AICEP), the Polish Central Statistical Office (GUS), and the Polish-Portuguese Chamber of Commerce (PPCC). These databases helped in obtaining the newest and the most relevant 
data regarding Portuguese investment in Poland. Having recent information is crucial to providing a meaningful overview of the topic.

For our study, an anonymous online questionnaire was conducted to survey the opinions of Portuguese investors about investing in Poland. The questionnaire contained questions regarding parent companies, Polish subsidiaries, factors determining the location in Poland, among other questions. The survey contained four questions on a 5 -point Likert scale ( $1=$ not important, $5=$ very important).

A list of companies with Portuguese capital in Poland was obtained on 2 December 2013 from the website of the Trade and Investment Promotion Section of Embassy of the Republic of Poland in Lisbon. The questionnaire was sent via e-mails in March, April and May 2014 to 106 out of 125 companies of the list (19 companies of the aforementioned list were inactive or in liquidation).

There were 20 complete replies. According to Cvent, a company that provides online solutions for events and surveys, the usual response rate for an external online survey is around $10-15$ per cent. According to the online marketing company Constant Contact, 10-20 per cent is a common survey response rate. Thus, the 18.9 per cent response rate for our survey allowed a meaningful analysis based on the data obtained. Although the response rate was high, the sample size was small. The number of responses was insufficient to conduct a more rigorous statistical analysis - through hypothesis testing, for example. For this reason, the data obtained were subjected to an exploratory analysis, as described in the next section.

With respect to company's age, the majority of survey respondents $(70 \%)$ have been in business between 10 and 20 years in the home country, 15 per cent of companies have less than 10 years in the market, and 15 per cent of respondents have more than 20 years of activity. Consequently, it is concluded that most of the companies of the sample are companies that have several years of experience in their field of activity.

One of the main factors in determining whether a company is micro, small, medium or large is the number of employees. A micro enterprise is defined as an enterprise which employs fewer than 10 persons. Small enterprises employ between 10 and 50 persons. Medium-sized companies employ between 50 and 250 persons, large businesses have over 250 employees (European Commission, 2005), and usually have more funds for undertaking FDI (Buckley, 2003). Forty per cent of the respondents in our survey were large companies, and 35 per cent were micro companies. 
In regard to the age of the Polish subsidiaries, most are relatively young: 70 per cent of them have less than 10 years of experience in the Polish market. This fact might be connected with the accession of Poland to the European Union in May 2004. After accession to the EU, the Polish economy received a lot of FDI, and started to lead in attracting investors in CEE region in terms of annual flow.

In this study, 'industry' was classified according to the Global Industry Classification Standard (GICS). The largest respondent groups represent the Textiles \& Apparel industry and the Food \& Beverage industry (with $25 \%$ and $15 \%$, respectively), followed by Retail \& Retail Distribution, Real Estate \& Construction, Information Services and Financial Services (each sector having $10 \%$ of responses).

Regarding the location of subsidiaries, the survey results show that most of the Portuguese companies (60\%) are located within the Mazowieckie Voivodeship. The Wielkopolskie Voivodeship is also appreciated by Portuguese investors (30\%). This result is similar to that of TPA Horwath Polska, who also found that the majority of Portuguese companies are located in Mazowieckie and Wielkopolskie regions. Somewhat surprising is the fact that the abovementioned regions are not connected with the SEZs. Thus, there could be other incentives that attract foreign investors to locate their investment in these regions. According to PAIilZ (2013), the Mazowieckie Voivodeship is the most attractive region in Poland.

Concerning the mode of establishment, the majority of Portuguese direct investments in Poland are greenfield investments. Only 20 per cent of the respondents indicated undertaking FDI in Poland by merger/acquisition. With respect to ownership, in most cases $(60 \%)$ the Polish subsidiaries are almost fully dependent on Portuguese equity (the share of Portuguese equity in the Polish subsidiary is higher than $75 \%$ ).

Another aspect to highlight is that 75 per cent of our Portuguese respondents stated that their Polish subsidiary involves all or almost all of the value chain. For the rest, the Polish subsidiary participates only in part of a wider value chain. Furthermore, for 70 per cent of respondents the subsidiary was the first option in the internationalisation process and for the rest, that is, 30 per cent, the Polish subsidiary is a consequence of a previous entry mode in Poland. Regarding the importance of investment in Poland, 14 of 20 firms who answered the questionnaire consider their investment in Poland as very important or important.

Most Portuguese investors (70\%) used self-research as their current source of information when making investment decisions in Poland. Many Portuguese 
entrepreneurs also appreciate the performance of the Portuguese-Polish Chamber of Commerce (50\%) and the market studies of professional consultancy companies (45\%) that help to facilitate and support the development of business. Respondents also indicated their own instruments, such as benchmarking and feedback from other retailers.

\section{Results}

\subsection{Location factors}

Respondents indicated factors determining the location of their business in Poland. They ranked the selected factors from 1 (not important) to 5 (very important).

One of the respondents stated that the access to large projects co-financed from the European Union is a very important factor determining the location of a business in Poland. In fact, since 2007 Poland has been the largest beneficiary of EU funds (the country received over 67 billion euros between 2007 and 2013) and will remain so until 2020. Between 2014 and 2020 Poland will receive almost 106 billion euros to invest in such areas as scientific research and its commercialisation, main road connections, eco-friendly transport, business development, etc. Figure 3 shows the mean of the answers obtained.

Furthermore, the large domestic market in Poland is also considered as a very important location factor for Portuguese investors. Poland is the sixth most populated country in the EU. Respondents indicated that market growth and Poland's strategic location are fairly important location factors. Once more, the fact that Portuguese investors in Poland are market-seekers has been proven. Poland is centrally positioned at the crossroads of Europe, and is called "the heart of the European continent". Ease of doing business, a stable political and economic environment and highly-qualified labour force are considered to be important location factors determining investing in Poland by Portuguese investors. Respondents stated that factors such as existence of SEZs, cheap labour force, access to raw materials or to new technology, lack of local competition and participation in clusters are of only slight importance when determining the location of a business in Poland. Results presented in Figure 3 suggest that Portuguese investors in Poland are market-seekers rather than resource-seekers.

The existence of any relationship between the aforementioned location factors was verified by Spearman's coefficient. Spearman's correlation coefficient 
Figure 3. Mean of the answers obtained regarding the factors determining the location of a business in Poland

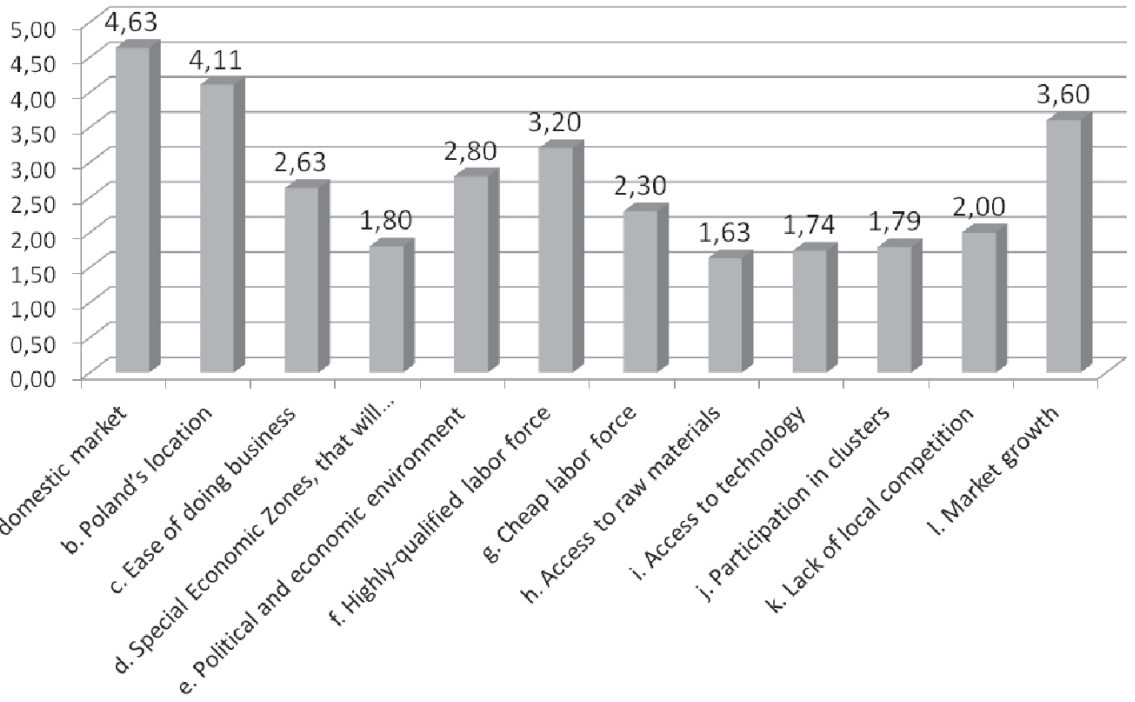

Source: Own elaboration based on the data obtained from the survey

can be either positive or negative and has a value between -1.00 and +1.00 (Wienbach \& Grinnell, 2007). After the Spearman test it was possible to indicate which location determinants are connected. Four strong correlations, significant at the 0.01 level, were found among the location factors used in the survey. The strong relationships between factors such as participation in clusters and access to technology $(0.901)$ and raw materials $(0.755)$ can be easily explained by the fact that being a member of a cluster allows a company to operate more productively, to access technology and information and thus achieve more rapid innovation (Porter, 1998). There is also a strong correlation between access to technology and access to raw materials (0.749). Furthermore, the political and economic environment affects business significantly. A stable and dynamic environment is fundamental for business growth (Jain et al., 2008). This is one reason for the strong correlation (0.673) between the political and economic environment and the ease of doing business factors.

\subsection{Obstacles}

Investors face many obstacles when it comes to undertaking FDI. Portuguese investors who participated in the survey indicated the main obstacles experienced while setting up the business in Poland. Figure 4 shows the mean of the answers obtained. Most respondents indicated that the language barrier is 
a very important obstacle for Portuguese investors, as Polish is one of the most difficult languages in the world.

Cultural differences are also noted by Portuguese investors as fairly important obstacles to FDI in Poland, along with bureaucracy and the fact that Poland does not use the euro as its currency. The rest of the obstacles to FDI in Poland such as an unstable legal system, high investment risk, political instability, weak infrastructure, non-qualified labour force and existing companies are considered as slightly important to not important.

Figure 4. Mean of answers obtained regarding the the main obstacles experienced while setting up business in Poland

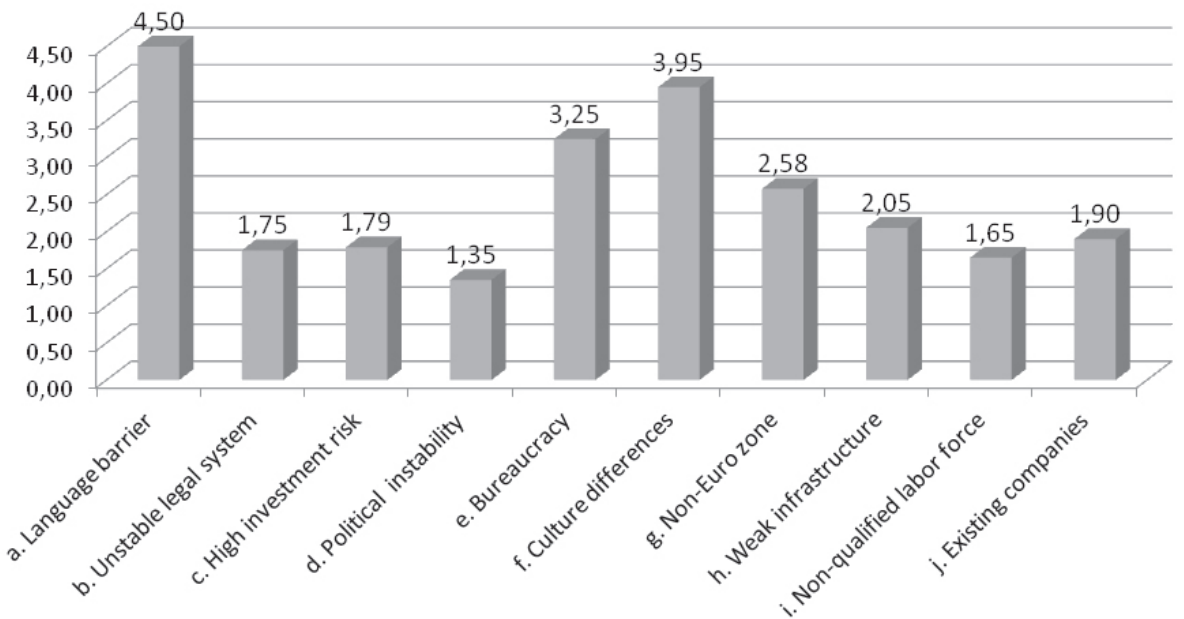

Source: Own elaboration based on data obtained from the survey

What should be highlighted is the fact that according to the EF English Proficiency Index Report (2013) Poland has made enormous progress in learning English. This report ranks countries by the average level of English skills among adults. Poland is ranked eighth in the high proficiency group. These English skills are a crucial step towards avoiding a language barrier when it comes to undertaking FDI.

The relationship between the obstacles was tested by Spearman's correlation as in the previous cases. Several strong correlations, significant at the 0.01 level, were found between the listed obstacles. The strongest correlations were between factors such as weak infrastructure and non-euro zone (0.782), political instability and high investment risk (0.749), existing companies and 
non-qualified labour force (0.725), non-qualified labour force and non-euro zone (0.713), and non-qualified labour force and weak infrastructure (0.711), among others.

\section{Conclusions}

The main goal of this study was to analyse what makes Poland an attractive FDI market and why each year more and more Portuguese firms choose Poland for investment. FDI location determinants have been broadly discussed in the literature, but only a few empirical studies focus on the motives for foreign direct investment in CEE, mainly in Poland. The present study addressed this gap in the literature, trying to analyse what makes Poland an attractive market for Portuguese investors, gaining a better understanding of reasons why Poland is an interesting location compared to its neighbours in the CEE.

To investigate this issue, a survey among Portuguese investors in Poland was conducted, concluding that the most decisive factor for locating a business in Poland is its large domestic market (market-seeking investment). This is in agreement with TPA Horwath's (2010) study. Poland's geographic position is also appreciated by Portuguese investors when deciding on location. The most significant obstacles to the Polish market indicated by Portuguese investors are the language barrier, culture differences and bureaucracy, also corroborating some results of TPA Horwath (2010). The results concerning location determinants and obstacles can help firms in their decision to invest in Poland and can also help the Polish government in designing policies aimed at attracting foreign investment.

As with any study, some limitations should be acknowledged. The present study relates to a very extensive topic that can be examined from different outlooks and focuses. Firstly, in order to have an accurate picture, a representative sample of the population needs to be surveyed. However, in this case, the population of interest was relatively small-125 companies, of which 19 are inactive or in liquidation. Therefore, the questionnaire was sent to all the companies-that is, to 106 . The main limitation is related to the number of responses obtained from Portuguese investors. This study received only 20 responses - a relatively small number and insufficient to conducting a more rigorous statistical analysis.

An interesting field for future research will be to analyse Portuguese FDI in other CEE countries and compare the results with Poland. Furthermore, another interesting approach for future research will be to analyse whether Portuguese FDI 
has had any impact on recent development of the Polish economy and to examine how Polish consumers perceive Portuguese companies and their products.

Patrycja Aleksandruk received her MA degree in Management from Faculty of Economics of University of Porto, Portugal, and her BA degree from the University of Economics in Poznań, Poland, in the field of International Economic Relations with major in International Business. Her research interests predominately focus on the international business field mainly on the Polish-Portuguese business relations. In the future, she would like to start a PhD Programme that will provide her the opportunity to continue research in this field.

Rosa Forte is Assistant Professor at the Faculty of Economics, University of Porto, and researcher at CEF.UP. She holds a PhD in Economics from the University of Porto. Her research interests predominately focus on FDI determinants and the foreign market entry mode. Recent peer-reviewed articles have focused on the impact of multinationals on host country market structure and the impact of industry characteristics on firms' export intensity.

\section{References}

AICEP (2013), Fluxos de Investimento Directo de Portugal com o Exterior 2012 (Janeiro a Dezembro). Retrieved from http://www.portugalglobal.pt/PT/Biblioteca/ Paginas/Homepage.aspx [accessed 1 Oct 2013]

— (2014), Fluxos de Investimento Direto de Portugal com o Exterior 1996-2013. Retrieved from http://www.portugalglobal.pt/PT/Biblioteca/Paginas/Homepage. aspx [accessed 20 Mar 2014]

Ali, S. \& Mirza, H. (1996), 'Market-Entry Strategies in Poland,' in J. Nowak (ed.) Marketing in Central and Eastern Europe, New York: The Haworth Press.

Anil, I.; Tatoglu, E. \& Ozkasap, G. (2014), 'Ownership and market entry mode choices of emerging country multinationals in a transition country: Evidence from Turkish multinationals in Romania,' Journal for East European Management Studies, vol. 19, no. 4, pp. 413-452.

Buckley, A. (2003), Multinational Finance, $5^{\text {th }}$ ed., Harlow: Financial Times/ Prentice Hall.

Cherunilam, F. (2008), International Economics, $5^{\text {th }}$ ed., New Dehli: Tata Mcgraw-Hill Publishing Company Ltd.

Chidlow, A.; Salciuviene, L. \& Young, S. (2009), 'Regional determinants of inward FDI distribution in Poland,' International Business Review, vol. 18, no. 2, pp. 119-133. http://dx.doi.org/10.1016/j.ibusrev.2009.02.004 
Cieślik, A. (2013), 'Determinants of the location of foreign firms in Polish regions: does firm size matter?' Tijdschrift voor Economische en Sociale Geografie, vol. 104, no. 2, pp. 175-193. http://dx.doi.org/10.1111/tesg.12017

(2005a), 'Regional Characteristics and the Location of Foreign Firms within Poland,' Applied Economics, vol. 37, no. 8, pp. 863-874.

http://dx.doi.org/10.1080/00036840500061087

- (2005b), 'The Location of Foreign Firms and National Border Effects: The Case of Poland,' Tijdschrift voor Economische en Sociale Geografie, vol. 96, pp. 287-297. http://dx.doi.org/10.1111/j.1467-9663.2005.00460.x

Cieślik, A. \& Ryan, M. (2005), 'Location Determinants of Japanese Multinationals in Poland: Do Special Economic Zones Really Matter for Investment Decisions?' Journal of Economic Integration, vol. 20, pp. 475-496.

http://dx.doi.org/10.11130/jei.2005.20.3.475

Dunning, J. H. (1998), 'Location and the Multinational Enterprise: A Neglected Factor?' Journal of International Business Studies, vol. 29, no. 1, pp. 45-66. http://dx.doi.org/10.1057/palgrave.jibs.8490024 (1980), 'Toward an eclectic theory of international production: some empirical tests,' Journal of International Business Studies, vol. 11, no. 1, pp. 9-31. http://dx.doi.org/10.1057/palgrave.jibs.8490593

Dunning, J. H. \& Lundan, S. M. (2008), Multinational Enterprises and the Global Economy, $2^{\text {nd }}$ ed., Cheltenham: Edward Elgar.

EF (2013), The EF English Proficiency Index 2013 REPORT. Retrieved from http:// www.ef.edu.pt/_/ /media/efcom/epi/2014/full-reports/ef-epi-2013-reportmaster-new.pdf [accessed 20 Jul 2014]

Embaixada da República da Polónia em Lisboa (2014), "Investimento português na Polónia”, Departamento de Promoção do Comércio e do Investimento. Retrieved from http://lisbon.trade.gov.pl/pt/parceiro/article/detail,3406,Investimento portugues_na_Polonia.html [accessed 20 Mar 2014]

Ernst \& Young (2013), Europe 2013: Coping with the crisis, the European way, Ernst $\&$ Young's attractiveness survey.

European Commission (2005), 'The new SME definition: user guide and model declaration.' Retrieved from http://ec.europa.eu/enterprise/policies/sme/files/ sme_definition/sme_user_guide_en.pdf [accessed 12 Jun 2014]

Gorynia, M.; Nowak, J. \& Wolniak, R. (2007), 'Motives and modes of FDI in Poland: An exploratory qualitative study,' Journal of East European Management Studies, vol. 12, no. 2, pp. 132-151.

Jain, T. R; Trehan, M. \& Trehan, R. (2008), Business Environment, New Dehli: V. K. Publications. 
Klug, M. \& Pietrzak, J. (2006), Market Entry Strategies in Eastern Europe in the Context of the European Union: An Empirical Research into German Firms Entering the Polish Market, Wiesbaden: Deutscher Universitäts-Verlag.

Morschett, D.; Schramm-Klein, H. \& Zentes, J. (2010), Strategic International Management: Text and Cases, $2^{\text {nd }}$ ed., Wiesbaden: Gabler Verlag. http://dx.doi.org/10.1007/978-3-8349-6331-4

OECD (2008), Benchmark Definition of Foreign Direct Investment, $4^{\text {th }}$ ed., Paris.

PAIiIZ (2013), Investment attractiveness of regions 2013. Retrieved from http://www. paiz.gov.pl/publications/regions [accessed 16 Nov 2014] (2014), EU Funds. Retrieved from http://www.paiz.gov.pl/why_poland/eu_funds [accessed 29 Jun 2014]

Porter, M. E. (1998), 'Clusters and the New Economics of Competition,' Harvard Business Review, Boston, November-December 1998 issue.

PPCC (2013), Câmara de Comércio Bilateral Polónia-Portugal, [Homepage] Retrieved from http://www.ppcc.pl [accessed 16 Nov 2014]

Sharan, V. (2012), International Business: Concept, Environment and Strategy, $3^{\text {rd }}$ ed., Delhi: Pearson Education India.

Shenkar, O. \& Luo, Y. (2007), International Business, $2^{\text {nd }}$ ed., Los Angeles, London, etc.: Sage Publications, Inc.

Simões, V. C. \& Cartaxo, R. M. (2012), 'Outward FDI from Portugal and its policy context, 2012,' Columbia FDI Profiles, New York: Vale Columbia Center on Sustainable International Investment.

Torrisi, D. R.; Delaunay, C. J.; Kocia, A. \& Lubieniecka, M. (2007), 'FDI in Poland: Determinants and Implications for Countries in Transition.' Presented at the Academy of International Business U.S. Northeast Chapter Regional Meeting, Portsmouth, New Hampshire.

TPA Horwath (2010), Portuguese investments in Poland, Warsaw. Retrieved from http:// amcham.pl/file/pdf/portuguese_investment_in_poland_v5_kkl.pdf?PHPSESSID= f2bc47d7b11c0403b0c32cf347232dc5 [accessed 12 Feb 2014]

UNCTAD (1998), World Investment Report 1998: Trends and Determinants, New York \& Geneva: United Nations Conference on Trade and Development. (1999), World Investment Report 1999: Foreign Direct Investment and the Challenge of Development, New York \& Geneva: United Nations Conference on Trade and Development.

(2002), World Investment Report 2002: Transnational Corporations and Export Competitiveness, New York \& Geneva: United Nations Conference on Trade and Development.

(2003), World Investment Report 2003: FDI Policies for Development: National and International Perspectives, New York \& Geneva: United Nations Conference 
on Trade and Development.

(2013), World Investment Report 2013: Global Value Chains: Investment and Trade for Development, New York \& Geneva: United Nations Conference on Trade and Development.

Wienbach, R. W. \& Grinnell, R. M., Jr. (2007), Statistics for Social Workers, $7^{\text {th }}$ ed., Boston: Pearson Education, Inc.

World Bank (2013), Doing Business 2013: Smarter Regulations for Small and MediumSize Enterprises, Washington, DC: World Bank Group. 